\title{
Cytogenetic investigation in prenatal specimens for effective prognosis of pregnancy related complications
}

\author{
Binay Kumar Raut ${ }^{1}$, Lakshman Kumar Balasubramanian ${ }^{2}$, Mukesh Kumar Jha ${ }^{3}$, \\ Shyam Sundar Malla ${ }^{1}$, Moka Rajasekhar ${ }^{4}$ \\ ${ }^{1}$ Department of Biochemistry, Kathmandu University School of Medical Sciences, Dhulikhel, Kavre, Nepal \\ ${ }^{2}$ Department of Biotechnology, Kongunadu Arts and Science College, Coimbatore, Tamilnadu, India \\ ${ }^{3}$ Department of Physiology, Kathmandu University School of Medical Sciences, Dhulikhel, Kavre, Nepal \\ ${ }^{4}$ Department of Biotechnology, School of Life Sciences, Manipal University, Manipal, Karnataka, India
}

\author{
Email address: \\ binaymolbio@gmail.com (B. K. Raut), laksh29@gmail.com (L. K. Balasubramanian), jhamukesh.jnp@gmail.com (M. K. Jha), \\ shyam_malla@hotmail.com (S. S. Malla),rsmoka@gmail.com (M. Rajasekhar)
}

\section{To cite this article:}

Binay Kumar Raut, Lakshman Kumar Balasubramanian, Mukesh Kumar Jha, Shyam Sundar Malla, Moka Rajasekhar. Cytogenetic Investigation in Prenatal Specimecimens for Effective Prognosis of Pregnancy Related Complications. American Journal of Biomedical and Life Sciences. Vol. 2, No. 2, 2014, pp. 46-54. doi: 10.11648/j.ajbls.20140202.13

\begin{abstract}
Background: Alterations in chromosomal content of mother and infant are central characteristics of various complications related to pregnancy and early childhood. About $60 \%$ of the pregnancy losses, $2-3 \%$ of all the neonates and $50 \%$ of childhood deafness, blindness, mental retardation and 1 to $10 \%$ of all the malignancies are directly due to genetic factors. Hence cytogenetic testing of pre and post natal samples can prove to be useful for discovery of non-invasive markers for prevention of such conditions beforehand. Aim of the study: The present study was carried out to detect numerical and structural abnormalities in 56 subjects with repeated miscarriages, bad obstetric history and sub fertility by analysing peripheral blood, products of conception (POC) material, and recovered cell lines from prenatal samples. Methods: Conventional cytogenetics: Peripheral blood culture (PBC) supplemented with mitogen Phytohemagglutinin (PHA), metaphase chromosomes was harvested after 72 hours for chromosome analysis. Tissue cytogenetics: Culture of solid tissue was used as a source for mitotic cells from products of conception (POC) from first trimester spontaneous abortions for aneuploidy detection; and Prenatal chromosome analysis was performed by either chorionic villus sampling (CVS)' amniotic fluid and cord blood after culture. Image acquisition and analysis was performed by using automated karyotyping (IKAROS) software based on G, C and R banding. Results: Chromosomal abnormalities were located in all types of specimens but were predominantly observed in recurrent pregnancy loss (RPL) and product of conception (POC) samples. Aberrations observed were mainly translocations, satellites, additions in RPL cases like 46,XX with instances of (D/D,D/G,G/Gassociations);45,XX,rob(13;14);46,XXt(4;21);46,XX,(9qh+);46,XX,(14ps+);46,XX, t $15 ; 6)$ and ploidy involving $67, \mathrm{XX}+; 64, \mathrm{XXX}+; 69, \mathrm{XXX} ; 63, \mathrm{XXX} ; 58, \mathrm{XX}+$ in the POC cases. Conclusion: Cytogenetic screening could provide to be a useful method for monitoring patients with abnormal pregnancies. The cytogenetic result is an independent prognostic indicator, with certain karyotypes associated with a good prognosis for the better treatment.
\end{abstract}

Keywords: Products of Conception (POC), Peripheral Blood Culture (PBC), Karyotyping (G, C and R Banding)

\section{Background and Introduction}

All species are affected by genetic diseases. Chromosomal manifestations are diverse and numerous, including early embryonic death, minor to major congenital defects, and infertility or sterility. Pregnancy loss is defined as the unexpected and unplanned spontaneous loss of pregnancy before the fetus becomes capable of extra uterine survival.

About $15 \%$ of all recognized pregnancies end in spontaneous abortions. The single most common reason is the presence of a chromosome abnormality in the fetus particularly if the loss occurs early in the pregnancy. Approximately $50 \%$ of such miscarriages are associated with cytogenetic abnormalities, with trisomy being the most frequent, followed by polyploidy and monosomy $\mathrm{X}$ [Kalousek et al., 1993]. Such miscarriages are thought to 
occur on a random basis, with an increasing frequency of trisomy with advancing maternal age [Hassold and Chiu, 1985]. More than $99 \%$ of chromosomally abnormal pregnancies result in miscarriage, most of which occur prior to 10 weeks gestation [Jacobs and Hassold, 1987]. About $60 \%$ of recurrent miscarriages might be caused by chromosomal aberrations in the embryo [Carp et al., 2004]. About 3-5\% of couples with recurrent miscarriage have one partner with balanced chromosomal rearrangement and carriers of reciprocal translocations are thought to have higher frequencies [Fred Kavalier 2005; Ogasawara et al., 2004].

With respect to cytogenetic studies in the above field, the most frequently applied human tissues are peripheral blood, amniotic fluid, chorionic tissue and skin fibroblasts. Amniocytes and chorionic cells are important in prenatal diagnostics [Eisenberg and Wapner 2002], and 1-15 days of cell culture are needed to obtain metaphase cells in this case [Wegner 1999]. Often, the cytogenetic results provide for definitive diagnosis and monitoring strategies.

The recent developments in molecular cytogenetic technologies, in association with conventional cytogenetic analysis, have improved the accuracy of the results and led to the finding of new chromosomal abnormalities. Hence a broad base of knowledge is necessary in order to understand, diagnose and advice patients about the complex field of pregnancy related complications.

\section{Aim of the Study}

The main aim of the present study was to perform cytogenetic analysis to detect numerical and structural abnormalities by using automated karyotyping (IKAROS) software in repeated miscarriage samples including products of conception (POC) material and recovered cell lines from prenatal samples

\section{Materials and Methods}

The present study was carried out to detect numerical and structural chromosomal abnormalities in 56 subjects (42 patients and 14 prenatal samples).

\subsection{Conventional Cytogenetics}

Peripheral blood culture (PBC) supplemented with mitogen Phytohemagglutinin (PHA) was setup and metaphase chromosomes were harvested after 72 hours for chromosome analysis after arrest by colchicines.

\subsection{Tissue Cytogenetics}

Culture of solid tissue was used as a source for mitotic cells from products of conception (POC) from first trimester spontaneous abortions for aneuploidy detection

After receiving the sample in Sodium saline, a small piece of the tissue was taken in a petridish. The tissue was washed with PBS at least 4 to 5 times and placed on a six well plate and supplemented with $3 \mathrm{ml}$ of DMEM with $10 \%$ FBS. The tissues were grown at $37^{\circ} \mathrm{C}$ in $\mathrm{CO} 2$ incubator and later transferred to a T25 flask. When the flask was $100 \%$ confluent, culture was trypsinized. After 48 hours incubation, cells were harvested. Metaphase cells were studied for the abnormalities.

Prenatal chromosome analysis was performed by amniotic fluid, chorionic villus sampling (CVS) and cord blood after culture.

The amniotic fluid collected was spun at $800 \mathrm{rpm}$ for 10 minutes. The pellet was suspendended in $5 \mathrm{ml}$ of growth medium (DMEM). The primary culture was setup i.e., the collected pellet in $3 \mathrm{ml}$ of Amniomax medium which contains $15 \% \mathrm{FBS}$, and distributed in three T25 flasks

For CVS and cord blood, the tissue culture method and blood culture method mentioned above was used

\subsection{High Resolution Prometaphase Chromosome Preparation}

In addition to routine chromosome culture, Methotrexate, Thymidine and Ethidium bromide were added to cultures for culture and harvest for high-resolution prometaphase chromosomes [Yunis et al. 1976]. Briefly, on the day prior to harvest was added $50 \mu \mathrm{l}$ of Methotrexate to block the DNA replication followed by incubation for another 16 hours. The next day was added $50 \mu 1$ of Thymidine and culture further incubated for another 3 hours. Finally $50 \mu 1$ of Ethidium bromide solution was added and culture incubated for one hour for excessive chromosome condensation. Then $50 \mu 1$ colcemid solution was added to culture, incubated for 30 minutes and harvested and studied.

$\mathrm{G}, \mathrm{R}$ and $\mathrm{C}$ banding techniques were performed as per the standard protocols and stained slides were screened for good metaphase spreads and the metaphases were captured under 100X oil immersion of the microscope (Ziess) attached with CCD camera. 50 metaphases were captured per sample and the karyotypes were analyzed with the help of Metasystem Ikaros software to detect any numerical or structural chromosomal abnormalities.

\section{Results}

Table 1 and 2 show the clinical data associated with the present study. The study included 42 patients who presented with repeated pregnancy loss, Bad obstetric history, subfertility and 14 products of conception and amniotic fluid samples. For the latter, recovered cell lines from miscarriage material and marker test positive samples were analysed (Figure 1).

It was found from the clinical data that the age groups of the patients were between 25-35 years.

Chromosomal abnormalities were located in all types of specimens using the three banding techniques namely G,R and $\mathrm{C}$ banding(Figure 2) but were predominantly observed in recurrent pregnancy loss (RPL) and product of conception (POC) samples(Figure 3). Aberrations observed were mainly translocations, satellites, additions in RPL 
cases like 46,XX with instances of $(\mathrm{D} / \mathrm{D}, \mathrm{D} / \mathrm{G}, \mathrm{G} / \mathrm{G}$ associations)(Figure 4); 46,XX,(15ps+)(Figure 5);46,XX, $\mathrm{t}(5 ; 6) \quad$ (Figure $\quad 6) 45, \mathrm{XX}, \mathrm{rob}(13 ; 14)$ (Figure 7);46,XXt(4;21);46,XX,(9qh+).46 XX (Figure 8) was predominant in amniotic fluid whereas Monosomy(Figure 9 and ploidy involving 67,XX+;64,XXX+;69,XXX(Figure

10) $; 63, X X X ; 58, X X+\quad, 81$ XXYY (Figure 11) were observed in the POC cases in addition to normal karyotypes.

Table 1. Cytogenetics data of Repeated pregnancy loss, Bad Obstetric History and subfertility patients

\begin{tabular}{|c|c|c|c|}
\hline S.No & $\begin{array}{l}\text { Age / } \\
\text { Sex } \\
\end{array}$ & Clinical diagnosis & Results \\
\hline 1. & $28 / \mathrm{F}$ & $\begin{array}{l}\text { Repeated Pregnancy } \\
\text { Loss (RPL) }\end{array}$ & $46, X X$ \\
\hline 2. & $28 / \mathrm{F}$ & RPL & $46, X X$ \\
\hline 3. & $27 / F$ & RPL & $46, X X$ \\
\hline 4. & $33 / \mathrm{F}$ & RPL & $46, X X$ \\
\hline 5. & $32 / \mathrm{F}$ & $\mathrm{BOH}$ & $46, X X$ \\
\hline 6. & $30 / \mathrm{F}$ & $\mathrm{BOH}$ & $46, X X$ \\
\hline 7. & $25 / \mathrm{F}$ & RPL & $\begin{array}{l}\text { 46,XX, Instances of } \\
\text { (D/D,D/G,G/G } \\
\text { associations) }\end{array}$ \\
\hline 8. & $25 / \mathrm{F}$ & RPL & $46, X X$ \\
\hline 9. & $28 / \mathrm{F}$ & RPL & $46, X X$ \\
\hline 10. & $36 / \mathrm{F}$ & RPL & $46, \mathrm{XX}$ \\
\hline 11. & $25 / \mathrm{F}$ & RPL & $46, X X$ \\
\hline 12. & $25 / \mathrm{F}$ & RPL & $46, \mathrm{XX}$ \\
\hline 13. & $25 / \mathrm{F}$ & RPL & $46, X X$ \\
\hline 14. & $28 / \mathrm{F}$ & RPL & $46, X X$ \\
\hline 15. & $25 / \mathrm{F}$ & $\begin{array}{l}\text { One miscarriage and } \\
\text { infertility }\end{array}$ & $45, \mathrm{XX}, \operatorname{rob}(13 ; 14)$ \\
\hline 16. & $28 / \mathrm{F}$ & $\mathrm{BOH}$ & $46, \mathrm{XX},(15 \mathrm{ps}+)$ \\
\hline 17. & $30 / \mathrm{F}$ & RPL & $46, X X$ \\
\hline 18. & $27 / \mathrm{F}$ & RPL & $46, \mathrm{XX}$ \\
\hline 19. & $29 / \mathrm{F}$ & $\mathrm{BOH}$ & $46, X X$ \\
\hline 20. & $20 / \mathrm{F}$ & $\mathrm{BOH}$ & $46, X X$ \\
\hline 21. & $26 / \mathrm{F}$ & RPL & $46, \mathrm{XX}$ \\
\hline 22. & $33 / \mathrm{F}$ & RPL & $46, X X$ \\
\hline 23. & $27 / \mathrm{F}$ & $\mathrm{BOH}$ & $46, X X$ \\
\hline 24. & $23 / \mathrm{F}$ & RPL & $46, X X$ \\
\hline 25. & $28 / \mathrm{F}$ & RPL & $46, \mathrm{XX}$ \\
\hline 26. & $23 / \mathrm{F}$ & RPL & $45, \mathrm{XX}, \operatorname{rob}(13 ; 14)$ \\
\hline 27. & $27 / \mathrm{F}$ & RPL & $46, \mathrm{XX}$ \\
\hline 28. & $28 / \mathrm{F}$ & RPL & $46, X X$ \\
\hline 29. & $30 / \mathrm{F}$ & RPL & $46, \mathrm{XX}, \mathrm{t}(4 ; 21)$ \\
\hline 30. & $23 / \mathrm{F}$ & RPL & $46, X X$ \\
\hline 31. & $27 / \mathrm{F}$ & RPL & $46, \mathrm{XX}$ \\
\hline 32. & $28 / \mathrm{F}$ & RPL & $46, X X$ \\
\hline 33. & $29 / \mathrm{F}$ & RPL & $46, X X$ \\
\hline 34. & $25 / \mathrm{F}$ & RPL & $46, X X$ \\
\hline 35. & $26 / \mathrm{F}$ & RPL & $46, \mathrm{XX},(9 \mathrm{qh}+)$ \\
\hline 36. & $26 / \mathrm{F}$ & RPL & $46, \mathrm{XX},(14 \mathrm{ps}+)$ \\
\hline
\end{tabular}

\begin{tabular}{llll}
\hline S.No & $\begin{array}{l}\text { Age } / \\
\text { Sex }\end{array}$ & Clinical diagnosis & Results \\
\hline 37. & $25 / \mathrm{F}$ & RPL & $46, \mathrm{XX}$ \\
38. & $28 / \mathrm{F}$ & BOH & $46, \mathrm{XX}$ \\
39. & $23 / \mathrm{F}$ & RPL & $46, \mathrm{XX}, \mathrm{t}(5 ; 6)$ \\
40. & $25 / \mathrm{F}$ & RPL & $46, \mathrm{XX}$ \\
41. & $28 / \mathrm{F}$ & RPL & $46, \mathrm{XX}$ \\
42. & $30 / \mathrm{F}$ & RPL & $46, \mathrm{XX}$ \\
\hline
\end{tabular}

Table 2. Cytogenetic analysis for recovered cell lines from amniotic fluid, Products of conception of triple marker positive and miscarriage patients respectively

\begin{tabular}{llll}
\hline S.No & $\begin{array}{l}\text { Cell lines and Initial } \\
\text { Karyotype }\end{array}$ & $\begin{array}{l}\text { Recovered cell lines } \\
\text { Karyotype }\end{array}$ & Source \\
\hline 1. & $45, \mathrm{X}$ & $67, \mathrm{XX}+$ & $\mathrm{POC}$ \\
2. & $46, \mathrm{XY}$ & $46, \mathrm{XY}$ & $\mathrm{POC}$ \\
3. & $46, \mathrm{XY}$ & $46, \mathrm{XY}$ & $\mathrm{POC}$ \\
4. & $46, \mathrm{XX}$ & $64, \mathrm{XXX}+$ & $\mathrm{POC}$ \\
5. & $46, \mathrm{XY}$ & $46, \mathrm{XY}$ & $\mathrm{POC}$ \\
6. & $46, \mathrm{XX}$ & $46, \mathrm{XX}$ & $\mathrm{POC}$ \\
7. & $69, \mathrm{XXX}$ & $69, \mathrm{XXX}$ & $\mathrm{POC}$ \\
8. & $46, \mathrm{XX} / 47, \mathrm{XY}+16$ & $63, \mathrm{XXX}$ & $\mathrm{POC}$ \\
9. & $46, \mathrm{XX},(15 \mathrm{ps}+)$ & $58, \mathrm{XX}+$ & $\mathrm{POC}$ \\
10. & $46, \mathrm{XX}$ & $46, \mathrm{XX}$ & $\mathrm{AF}$ \\
11. & $46, \mathrm{XY}$ & $46, \mathrm{XY}$ & $\mathrm{AF}$ \\
12. & $46, \mathrm{XX}$ & $46, \mathrm{XX}$ & $\mathrm{AF}$ \\
13. & $46, \mathrm{XX}$ & $46, \mathrm{XX}$ & $\mathrm{AF}$ \\
14. & $46, \mathrm{XX}$ & $46, \mathrm{XX}$ & $\mathrm{AF}$ \\
\hline
\end{tabular}

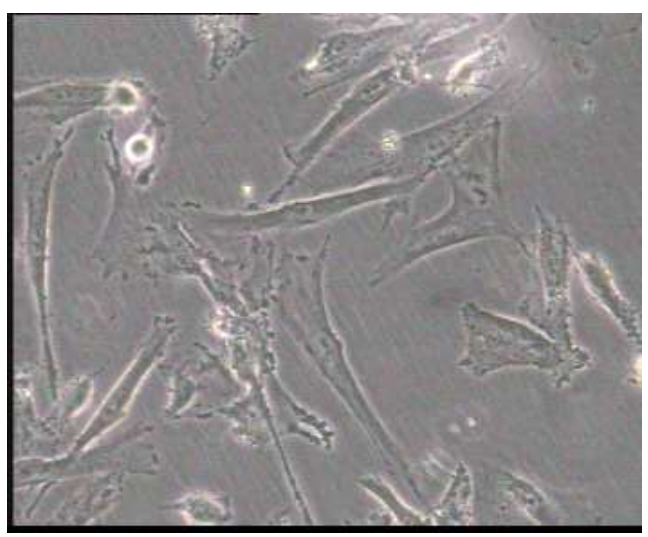

Figure 1. Recovered cell lines from amniotic fluid sample (Fibroblast cells) 


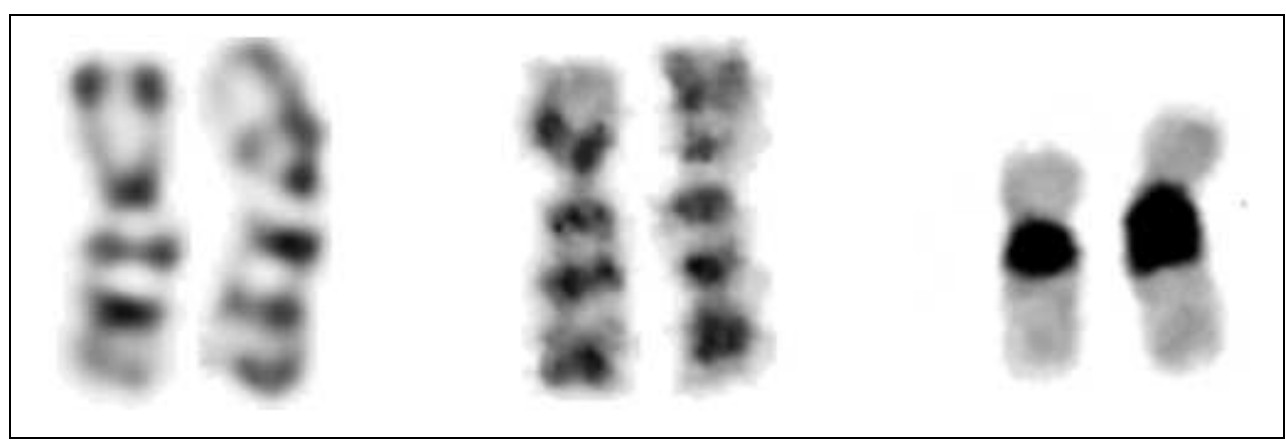

Figure 2. Different banding techniques $G$ banding, $R$ banding and $C$ banding

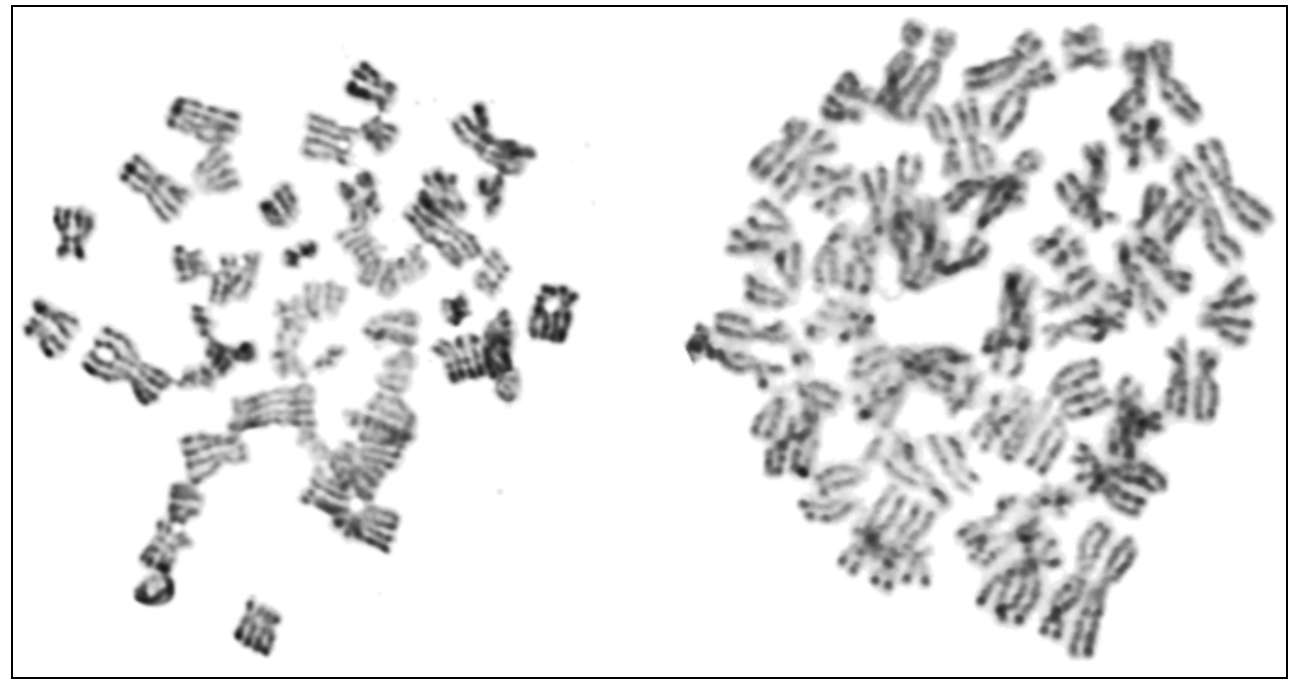

Figure 3. A placental tissue from products of conception - Endoreduplication

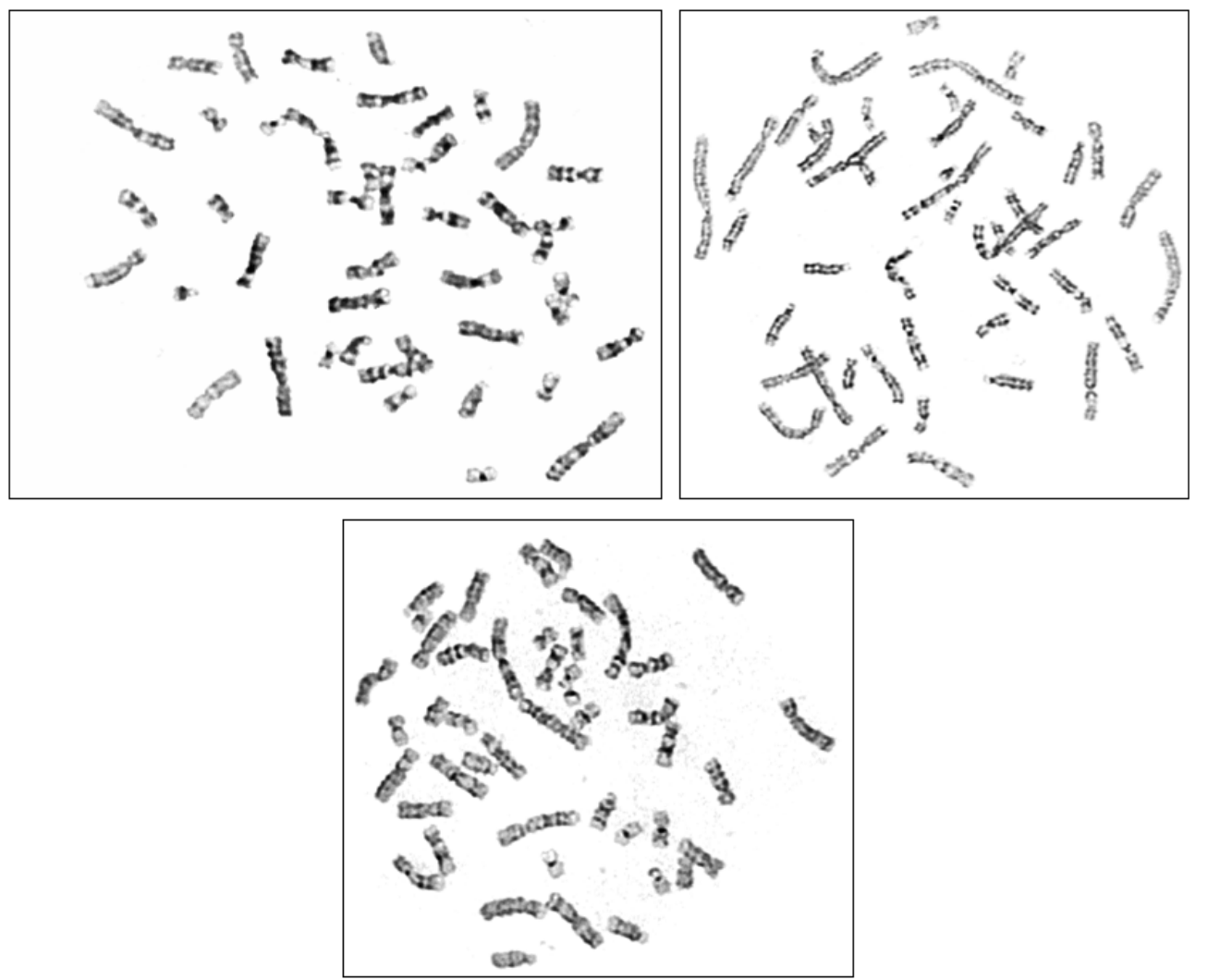

Figure 4. D/D, $D / G$ and $G / G$ associations (H/o repeated miscarriages) 

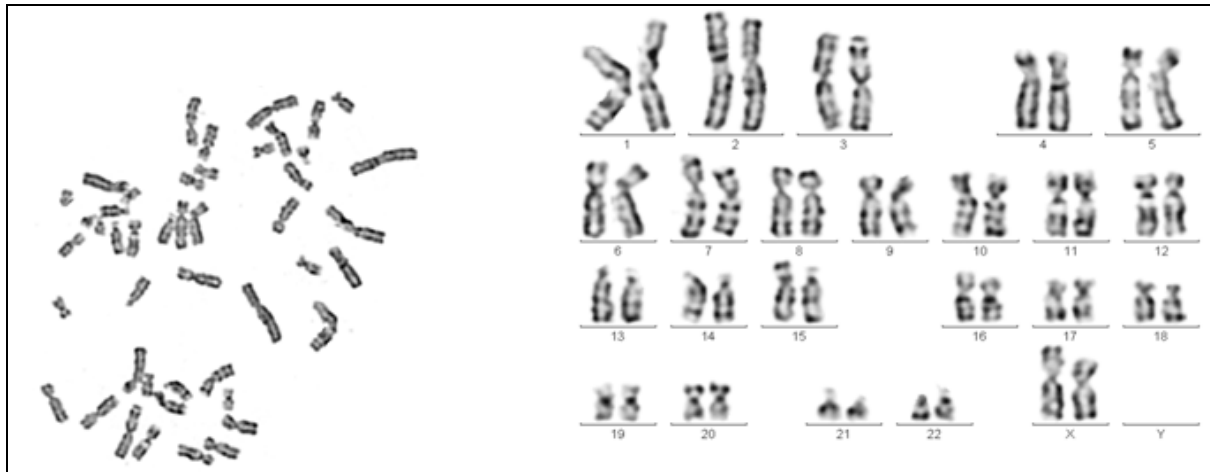

Figure 5. 46,XX,(15ps+) in a female with Bad Obstetric History

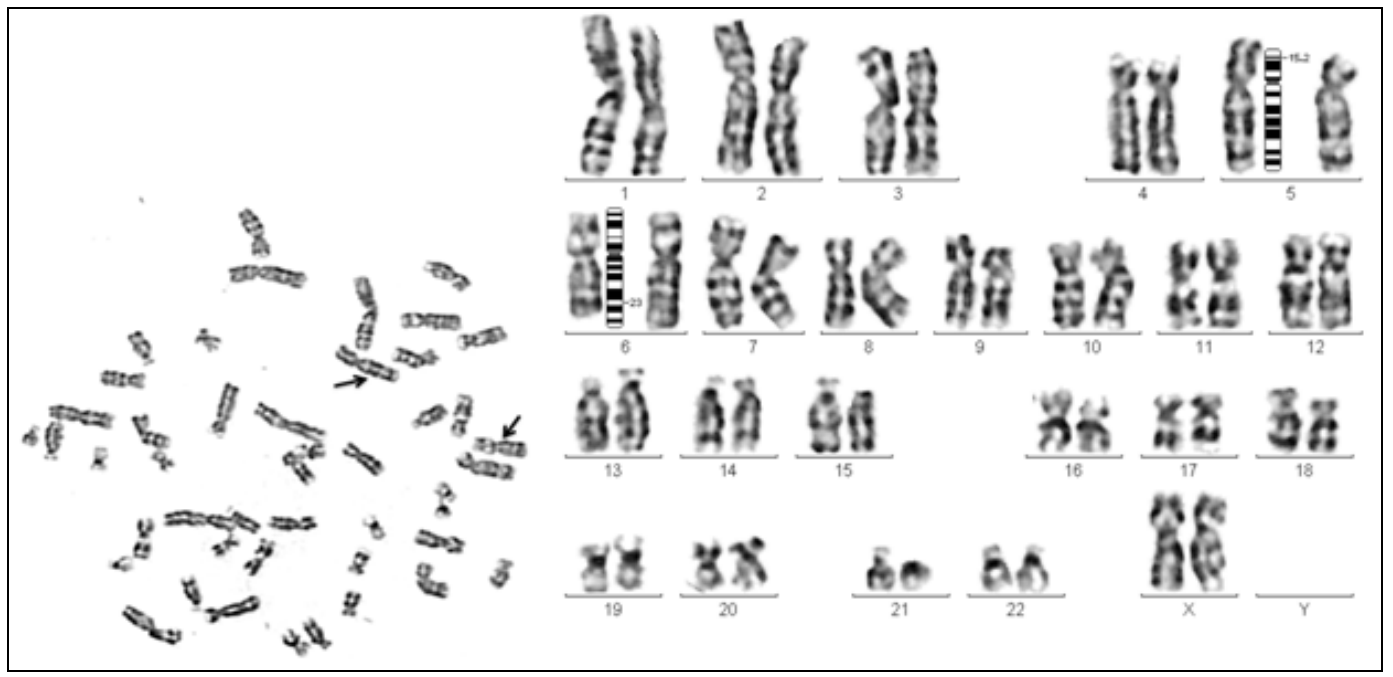

Figure 6. Karyotype 46, XX.t $(5 ; 6)$ - in a patient with repeated miscarriages

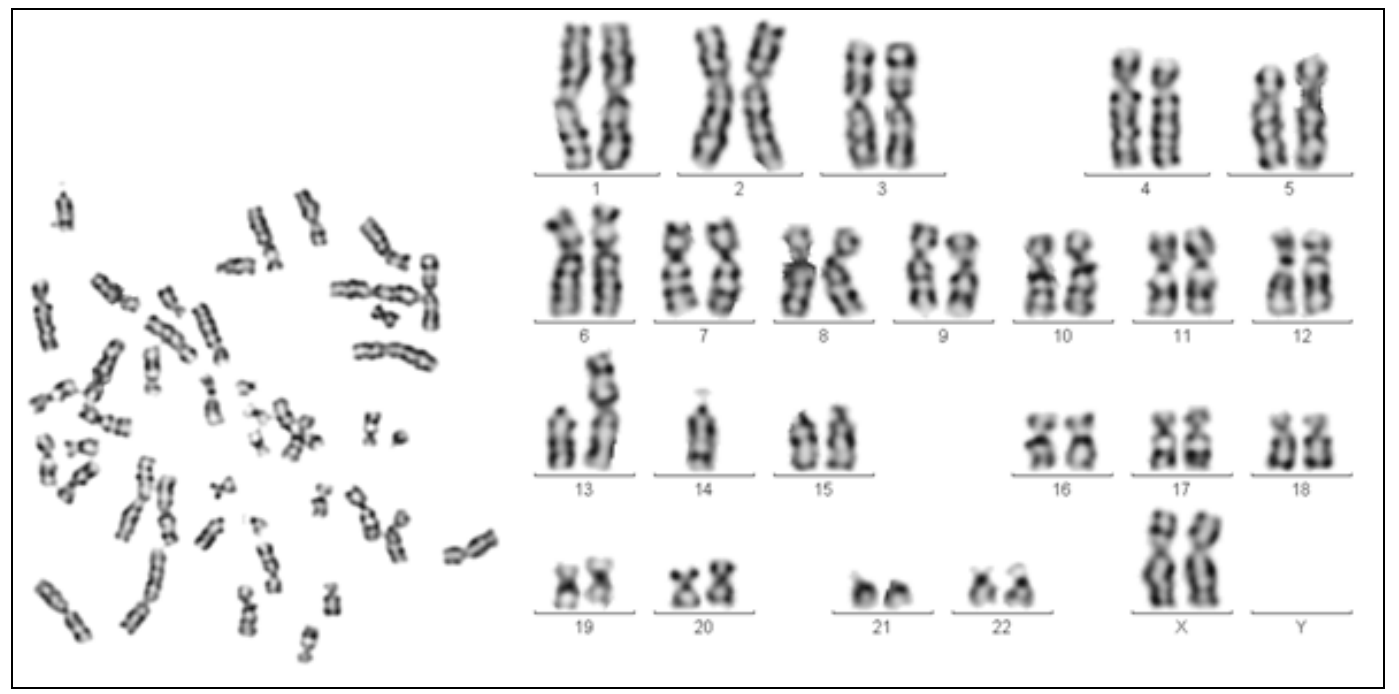

Figure 7. 45, XX, rob $(13 ; 14))$ - in patient with missed abortion and subsequent infertility 


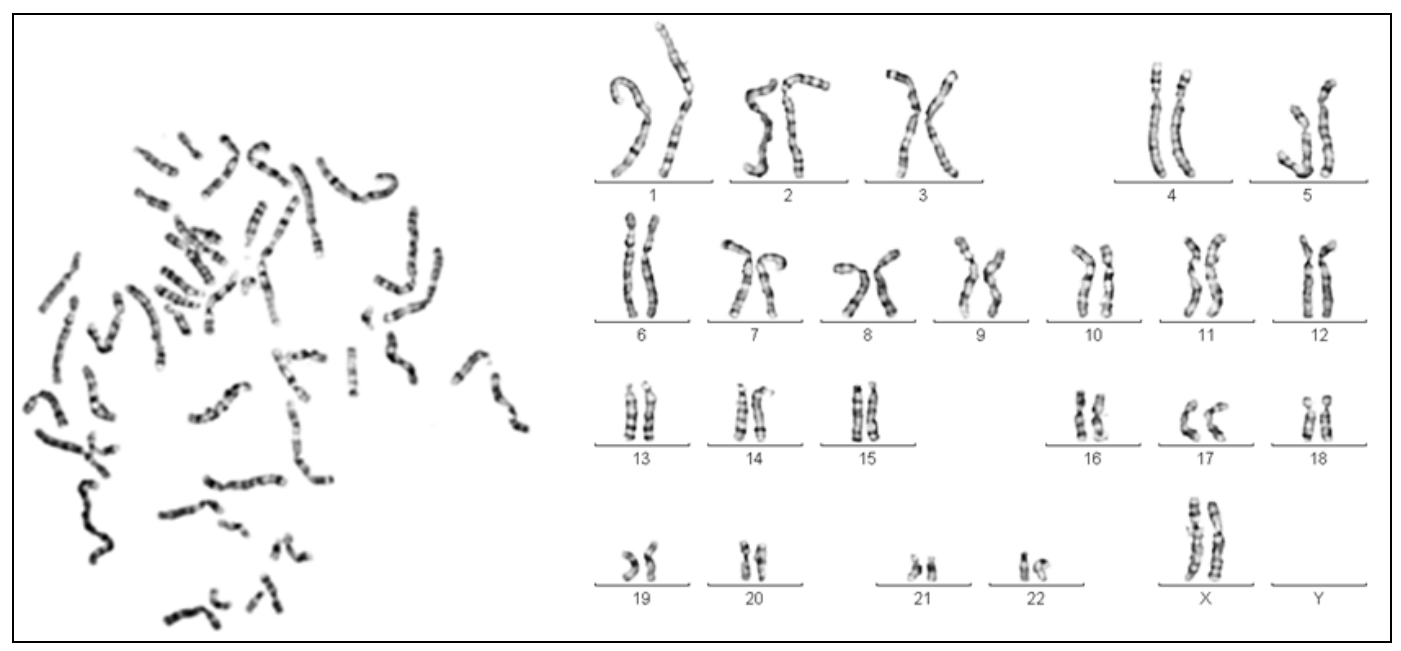

Figure 8. 46,XX karyotype (Amniotic fluid culture)

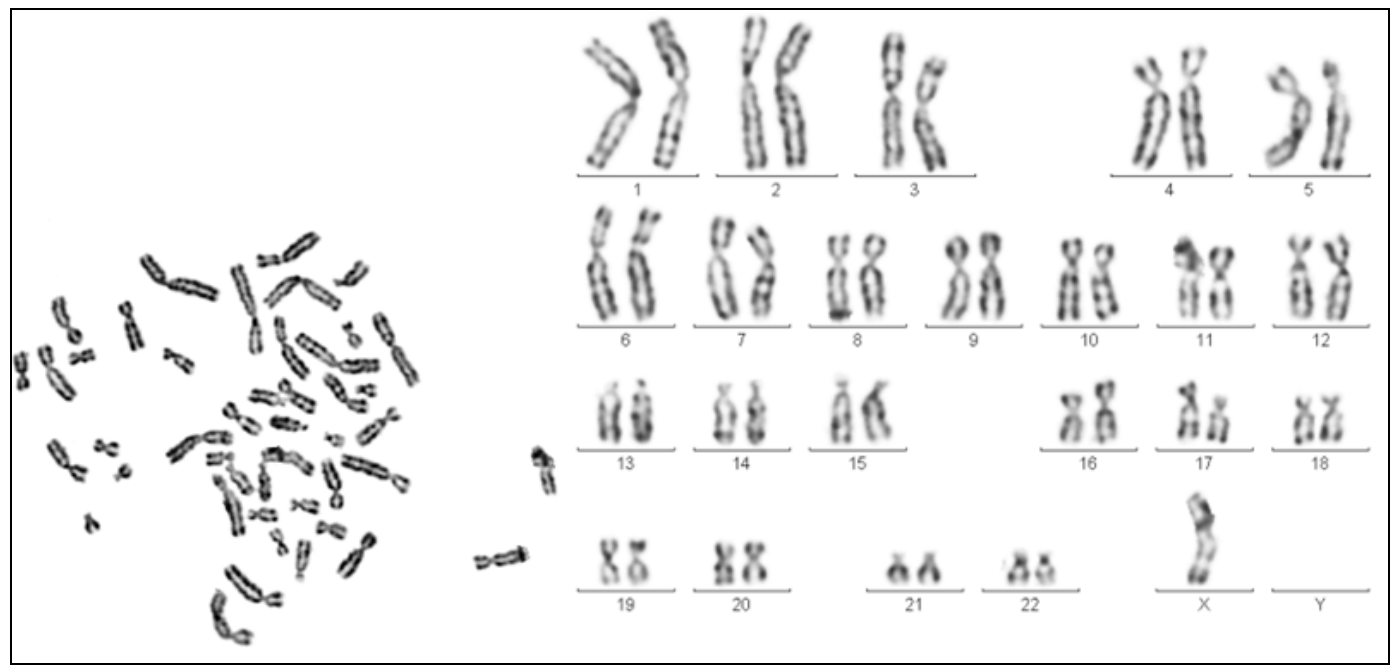

Figure 9. Monosomy $(45, X)$ in missed aborted material (POC)

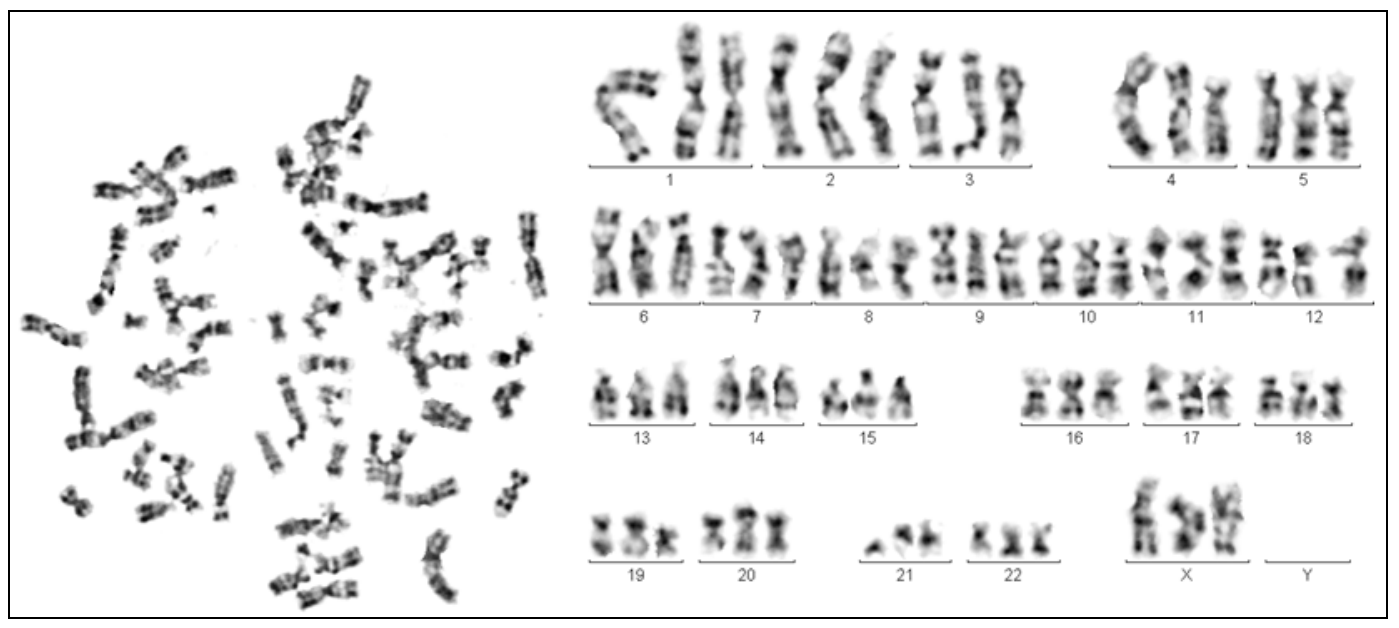

Figure 10. Triploidy (Products of conception sample) 


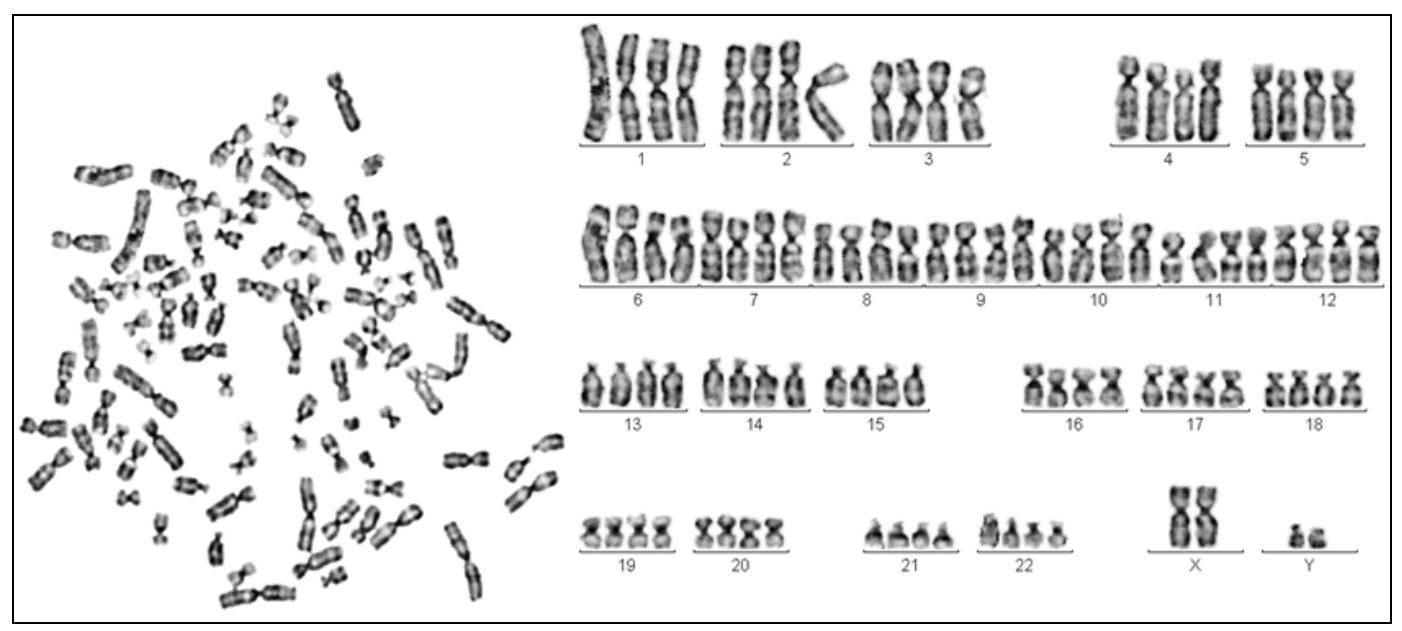

Figure 11. Tetraploidy (Products of conception sample)

\section{Conclusion}

Here we report different numerical and structural abnormalities in different prenatal specimens which could be further probed and investigated to serve as markers for pregnancy related complications. Hence cytogenetic screening could provide to be a useful method for monitoring patients with abnormal pregnancies. The cytogenetic result is an independent prognostic indicator, with certain karyotypes associated with a good prognosis for the better treatment.

Early identification of the possible cause of fetal loss can significantly reduce long term psychological distress in women with miscarriages and enables improved genetic counseling for those couples in future pregnancies.

\section{References}

[1] Alter BP. Clinical features of Fanconi's anaemia. In: Young NS, Alter BP, eds. Aplastic anemia: acquired and inherited. Philadelphia: Saunders, 1994:275-308.

[2] Amor-Gueret M. Bloom's syndrome. Orphanet encyclopedia. [cited on 2004. Available from: ttp//www.orpha.net/.

[3] Andaloussi El and Bilhou-Nabera C (2007) Case Report New Complex Chromosomal Translocation in Chronic Myeloid Leukaemia: $\mathrm{t}(9 ; 18 ; 22)(\mathrm{q} 34 ; \mathrm{p} 11 ; \mathrm{q} 11) \quad \mathrm{J}$. Biomedicine and Biotechnology Vol 2007, Article ID 92385, 3 pages.

[4] Arrighi FE and Hsu TE (1971) Localization of heterochromatic regions of human chromosomes. Cytogenetics 10; 81-86.

[5] Auerbach, A D., Adler, B., and Chaganti, R. S. K. (1981). Prenatal and postnatal diagnosis and carrier detection of Fanconi anemia by the cytogenetic method. Pediatrics, 67, 128-35.

[6] Auerbach, A. D., Buchwald, M., and Joenje, H. (2001). Fanconi anemia. In: The Metabolic and Molecular Bases of Inherited Disease,(Eds. CR Scriver, WS Sly, B Childs, et al.), 1, 753-68 McGraw-Hill, New York.
[7] Bagby, G. C., Lipton, J. M., Sloand, E. M., and Schiffer, C. A. (2003).Marrow failure. J. Med. Genet., 40, 1-10.

[8] Bennett JM, Catovsky D, Daniel MT, Flandrin G, Galton DA, Sultan C. (1952) Proposals for the classification of the myeloidysplastic syndrome. Br J Hematol 1952; 51: 189199

[9] Bloom D (1954) Congenital telangeetatic erythema resembling lupus erythematosus in dwarfs. Am J. Dis child $88 ; 754-758$.

[10] Brady K, Duff P, Harlass FE, Reid S (1991). Role of amniotic fluid cytogenetic analysis in the evaluation of recent fetal death Am J Perinatol;8(1):68-70.

[11] Carp H, Feldman B, Oelsner G, Schiff E. (2004) Parental karyotype and subsequent live births in recurrent miscarriage. Fertil Steril 81; 1296-1301.

[12] Carp H, Toder V, Aviram A, Daniely M, Mashiach S and Barkai G (2001) Karyotype of the abortus in recurrent miscarriage. Fertil Steril 75,678-682.

[13] Carrera M (2001) Screening prenatal de aneuploidı' as: QFPCR y FISH. Prog Diag Prenat 13,262-266.

[14] Caspersson T, Zech L, Johansson C: Differential binding of alkylating fluorochromes in human chromosomes. Exp Cell Res 1970, 60:315-319.

[15] Chandley AC (1983). Infertility and recurrent abortion In. Emery AEH, Rimoin (Eds). Principles and practice of Medical genetics, Churchill Livingston, New York.

[16] de Braekeleer M (1987) "Variant Philadelphia translocations in chronic myeloid leukemia," Cytogenetics and Cell Genetics, vol. 44, no. 4, pp. 215-222, 1987.

[17] Dicken CH, Dewald G, and Gordon H (1978) Sister chromatid exchanges in Bloom syndrome. Arch Dermatol 114(5); 755-760.

[18] Dutrillaux B (1973) Nouveau systeme de marquage Chromosomeiqe les bandes T. Chromosoma 41; 395;402.

[19] Eisenberg B, Wapner RJ (2002) Clinical procedures in prenatal diagnosis. Best Pract Res Clin Obstet Gynaecol 16:611-627. 
[20] Ellis NA, German J. Molecular genetics of Bloom's syndrome. Hum Mol Genet 1996;5:1457-63.

[21] Fred Kavalier (2005) Investigation of recurrent miscarriages BMJ. 2005 July 16; 331(7509): 121-122.

[22] Fryns JP, Kleczkowska A, Kubien E, Petit P, Vanberghe H (1984) Cytogenetic survey in couples with recurrent fatal wastage. Hum Genet 65;336-354.

[23] German J and Crippa LP (1966) chromosomal breakage in diploid cell lines from Bloom's syndrome and Fanconi's anemia. Ann Genet 9: 143-154.

[24] Goodpasture C Bloom SE, Hsu TC and Arrighi FE (1975) Human nucleolus organizers: the satellites or the stalks? Am J Hum Genet 28;;559-566.

[25] Hassold, T. and Chiu, D. (1985) Maternal age specific rates of numerical chromosome abnormalities with special reference to trisomy. Hum. Genet., 70, 11-17.

[26] Hatice Ilgin, Ayse Nurten Akarsu, Fatma Isik Bökesoy (1999) Cytogenetic and Phenotypic Findings in Turkish Patients With Fanconi's Anemia Tr. J. of Medical Sciences 29; 151154

[27] Horrike S, Taniwaki M, Misawa S, Abe T (1988) Chromosome abnormalities and karyotypic evolution 83 patients with myelodysplastic syndrome and predictive value for prognosis. Cancer 62: 1129-38.

[28] Hossein Mozdarani, Anahita Mohseni Meybodi, Shabnam Zari-Moradi (2008) A cytogenetic study of couples with recurrent spontaneous abortions and infertile patients with recurrent IVF/ICSI failure. Indian J of Hum Genet 14(1) 1-6.

[29] Hsu, T. C. Mammalian chromosomes in vitro, I. Karyotype of man. Journal of Heredity 43, 167-172 (1952).

[30] Jacobs P.A. and Hassold T.J. (1987) Chromosome abnormalities: origin and etiology in abortions and live births. In Vogal, F. and Sperling, K. (eds), Human Genetics. Springer-Verlag, Berlin, pp. 233-244.

[31] Jacobs RH, Cornbleet MA, Vardiman JW, Larson RA, Le Beau MM, Rowley JD(1986) Prognostic implications of morphology and karyotype in primary myelodysplastic syndromes. Blood 67:1765-72.

[32] Jemal A, Thomas A, Murray T, Thun M (2002). "Cancer statistics, 2002". CA Cancer J Clin 52 (1): 23-47.

[33] Jim Martin Southern Ontario Fertility Technologies (S.O.F.T.) 555 Southdale Rd., E., Suite 107, London, Ontario, N6E 1A2.

[34] Joenje H, Oostra AB, Wijker M, Di SFM, Van BCG, Rooimans MA, Ebell W, Van WM, Pronk JC, Buchwald M, Arwert F (1997). Evidence for at least eight Fanconi anemia genes. Am J Hum Genet;61:940-944.

[35] Kadam PR, Nangangund GJ, Advani SH (1990), The occurrence of variant $\mathrm{Ph}$ translocation in chronic myeloid leukemia (CML); a report of 6 cases. Hematol Oncol 8; 303-312.

[36] Kalousek, D.K., Pantzar, T., Tsai, M. et al. (1993) Early spontaneous abortion: morphologic and karyotypic findings in 3,912 cases. Birth Defects, 29, 53-61.
[37] Kim JM, Sim AS, Lee EH (2006) Amniotic chromosome analysis in pregnant women identified by triple marker testing as screens positive. Korean J Lab Med 26(2); 12330 .

[38] Lerardi-Curto L (2009) Chromosomal breakage syndromes. eMedicine Pediatrics, Webmed.

[39] Marquard K, Westphal LM, Milki AA and Lathi RB (2009) Etiology of recurrent pregnancy loss in women over the age of 35 years. Fertil Steril $30^{\text {th }}$ July 2009.

[40] Mitelman F (1993), "The cytogenetic scenario of chronic myeloid leukemia," Leukemia and Lymphoma, vol. 11, pp. $11-15,1993$.

[41] Mitelman F, Johansson B, and Mertens F (2006). Eds, "Mitelman Database of Chromosome Aberrations in Cancer," http://cgap .nci.nih.gov/Chromosomes/Mitelman, August 2006.

[42] Moorhead, P.S., Nowell, P.C., Mellman, W.J., Battips, D.M. and Hungereford, D.A. (1960). Chromosome preparations of leukocytes cultured from human peripheral blood. Exp. Cell Res. 20: 613-616.

[43] Naeimeh Tayebi, Hossain Khodaei (2008) Bloom's syndrome in a 12-year-old Iranian girl Ind J. Hum Genet $14(3) ; 103-105$.

[44] Nowell, P., \& Hungerford, D. A minute chromosome in human chronic granulocytic leukemia. Science 132, 1497 (1960).

[45] Ogasawara M, Ozaki Y, Sato T, Suzumori N, Suzumori K (2004) Poor prognosis of recurrent aborters with either maternal or paternal reciprocal translocations. Fertil Steril $81 ; 367-373$

[46] Reid DE, Ryan KJ, Benirsche K. (1972) Principles and management of human reproduction, Saunders, Philadelphia, London, Toronto.

[47] Rowley JD (1973) "A new consistent chromosomal abnormality in chronic myelogenous leukaemia identified by quinacrine fluorescence and Giemsa staining," Nature, vol. 243, no. 5405, pp.290-293, 1973.

[48] Sandberg A. A (1980) The Chromosomes in Human Cancer and Leukemia, Elsevier North Holland, New York, NY, USA, 1980

[49] Sanja cirkovic, Marija Guc-Scekic, Dragana Vujic and D micic (2006) Cytogenetic diepoxybutane sensitivity in Serbian children with Fanconi anemia. Arch Biol Sci Belgrade. 58 (4); 215-219.

[50] Santalo J, Catala V and Badenas J (1987) Chromosomal abnormalities and IVF. In Egozcue J (ed.) Cellular Aspects of In Vitro Fertilization. Cell Biology Reviews. Leiola, pp. $63-72$.

[51] Schoch C and Haferlach T (2007) Cytogenetics in acute myeloid leukemia. Current Oncology Report vol. 4(5) 390391.

[52] Schroeder TM, Tilgen D, Kruger J, Vogel F. Formal genetics of Fanconi's anemia. Hum Genet 1976;32:257-88.

[53] Seabright M (1971) A rapid banding technique for human chromosomes. Lancet, 7731:971-972. 
[54] Shaffer LG, Tommerup N, ISCN 2005: An international system for cytogenetic nomenclature. S. Karger, Basel, Switzerland 2005.

[55] Shahrabani-Gargir L, Shomrat R, Yaron Y, Orr-Urtreger A, Groden J, Legum C. High frequency of a common bloom syndrome Ashkenazi mutation among Jews of polish origin Genet Test 1998;2:293-6.

[56] Shalev E, Zalel Y, Weiner E, Cohen H, Shneur Y (1994) The role of cordocentesis in assessment of mosaicism found in amniotic fluid cell culture. Acta Obstet Gynecol Scand; 73(2):119-22.

[57] Tjio, J. H., \& Levan, A. The chromosome number of man, Hereditas 42, 1-6 (1956)

[58] Toogeh Gl, Najafi AH, and Keyhani M (2003) Cytogenetic findings in acute myeloid leukemia. Acta Medica Iranica 41 (4) $227-232$.
[59] Verma RS, Babu A (1994) Human chromosomes: principles and techniques, 2nd edn McGraw-Hill, New York.

[60] Vundinti BR, Kerketta L, Jijina F and Ghosh K (2009) Cytogenetic study of myelodysplastic syndrome from India. Indian J Med Res 130: 155-159.

[61] Warburton D, Stein Z, Kline J, and Susser M, et al. (1980) Chromosome abnormalities in spontaneous abortion: data from the New York City study. In Porter IH and Hook EB (eds) Human Embryonic and Fetal Death. Academic Press, New York, pp. 261-287.

[62] Wegner RD (1999) Diagnostic cytogenetics. Springer, Berlin.

[63] Yunis JJ: High resolution of human chromosomes. Science 1976, 191:1268-1270. 